\title{
Correlation between endometrial dating of luteal phase days 6 and 10 of the same menstrual cycle
}

\author{
Human Reproduction Sector, Escola Paulista de Medicina/Universidade Federal de São Paulo - São Paulo, Brazil
}

\begin{abstract}
Context: Endometrial maturation, important in the diagnosis of infertile couples, has been evaluated since 1950 using the Noyes criteria. Nevertheless, there is no consensus regarding the most suitable period of the luteal phase for performing the biopsy. Objetive: This study evaluated the correlation between the histological dating of two endometrial biopsies performed in the same menstrual cycle, on luteal phase days six and ten. Design: Prospective study. Setting: Human Reproduction Division of the Federal University of São Paulo, referral center. Patients:Twenty-five women complaining of infertility had their menstrual cycles monitored by ultrasound and LH plasma levels, to obtain evidence of ovulation. Procedures: Endometrial biopsies were performed on luteal phase days $\mathrm{LH}+6$ and $\mathrm{LH}+10$ (luteal phase day $1=\mathrm{LH}+1=$ the day that follows $\mathrm{LH}$ peak). Dating was done according to morphometric criteria, in which an endometrium sample is considered out of phase if the minimum maturation delay is one day. On day $\mathrm{LH}+6$, blood was drawn for plasma progesterone level determination. Results: All patients had an ovulatory cycle (mean LH peak: $47.4 \mathrm{U} / \mathrm{L}$; mean follicular diameter on LH peak day: $18.9 \mathrm{~mm}$; mean endometrial thickness on LH peak day: $10.3 \mathrm{~mm}$; mean plasma progesterone level on day $\mathrm{LH}+6: 14.4 \mathrm{ng} / \mathrm{ml}$ ). 14 patients had both biopsies in phase; 5 patients had out of phase biopsies only on day $\mathrm{LH}+6 ; 3 \mathrm{had}$ out of phase biopsies only on day $\mathrm{LH}+10$ and 3 patients had out of phase biopsies on both days. McNemar's test showed no statistical difference between these data ( $p>33.36 \%$ ). Conclusions: The correlation found between the endometrial datings suggests that biopsies performed on either of these two days are suitable for evaluation of endometrial maturation.
\end{abstract}

UNITERMS: Endometrium anatomy and histology. Luteal phase. Female infertility.

\section{INTRODUCTION}

$\mathrm{E}$ valuation of the luteal phase of regularly cycling women complaining of infertility is directed towards the evaluation of corpus luteum activity and the action of progesterone on the endometrium.

\footnotetext{
Address for correspondence:

Jorge Haddad Filho

Setor de Reprodução Humana

Universidade Federal de São Paulo

Rua Botucatu, 725

São Paulo/SP - Brasil - CEP 04023-062
}

Endometrial maturation, whose role in human reproduction was first recognized by Jones,${ }^{(1)}$ is evaluated by the Noyes criteria. $^{(2)}$ However, new progress in reproductive physiology has raised controversies about these criteria, related to the cronological reference for sampling, ${ }^{(3)}$ the most suitable region of the uterine wall for biopsy ${ }^{(4)}$ and the histological analysis itself, whose subjectivity may cause enough interobserver variation to change the clinical procedures. ${ }^{(5)}$ Moreover, there is no absolute agreement about the luteal phase period most appropriate for performing the biopsy. ${ }^{(6)}$

This study evaluated the correlation between the histological dating of two endometrial samples, obtained by biopsies performed on luteal phase days 6 and 10 of the same menstrual cycle. 


\section{METHODS}

Twenty five regularly cycling healthy women, complaining of infertility for at least one year, voluntarily agreed to participate in the study group and gave their informed written consent. All procedures were also approved by the Medical Ethics Committee of the Universidade Federal de São Paulo.

Blood samples were drawn from patients between days one and five of the menstrual cycle, for basal plasma levels of LH, FSH and prolactin, measured by immunofluorimetry (normal ranges: FSH: 2.4 to $9.3 \mathrm{U} / \mathrm{L}$; LH: 1.5 to $10 \mathrm{U} / \mathrm{L}$; prolactin up to $14.5 \mathrm{ng} / \mathrm{ml}$ ). A transvaginal ultrasonograph was also done to evaluate uterine echoes.

From menstrual cycle day nine onwards, follicular diameter ${ }^{(7)}$ and endometrial thickness ${ }^{(8)}$ were measured daily by transvaginal ultrasound. When the dominant follicle reached at least $16 \mathrm{~mm}$, daily plasma $\mathrm{LH}$ level measurements were started, until an LH peak was demonstrated. The following day was taken as the first of the luteal phase $(L H+1)$.

Endometrial biopsies were done on days $\mathrm{LH}+6$ and LH+10 with the suction catheter Pipelle. In the first of these, the catheter was introduced with its subterminal orifice directed to the right uterine wall and in the second, to the left.

Histological analyses were done in the portion of the tissue nearest to the embolus. The specimen was fixed in formaldehyde $10 \%$ and sections of $4 \mathrm{~m} \mu$ thickness were stained with hematoxilin-eosin. Endometrial maturity was evaluated through morphometric analysis, ${ }^{(9)}$ taking into account four semi-quantitative parameters (amount of luminal secretion in the gland, pseudostratification of the glandular epithelium, stromal differentiation and edema), estimated on a scale from 0 to 3 , and two quantitative parameters (number of supraand subnuclear vacuoles in the glandular epithelium and the volume fraction of the gland occupied by the epithelium). These analyses were done by the same observer. According to the morphometric criteria, the endometrium was considered as immature (out of phase) if histological analysis showed a maturation delay of one or more days.

On day $L H+6$, blood was drawn for progesterone plasma level determination, which was considered to be normal if a value greater than $7 \mathrm{ng} / \mathrm{ml}$ was reached.

In the following cycle, an HSG was performed to evaluate the uterine cavity. Data were analysed by McNemar's test, the significance level being 5\%.

\section{RESULTS}

The 25 patients had ages between 16 and 38 years (mean 29.6 and standard deviation 5.1 years). The infertility period ranged from 12 to 144 months (mean 57.2 and standard deviation 35 months).

All patients showed ultrasonograph and hormonal evidence of ovulation and Table I shows the parameters of the cycles. The mean $\mathrm{LH}$ peak value was $47.3 \mathrm{U} / \mathrm{L}$ (range 23 to $91 \mathrm{U} / \mathrm{L}$; standard deviation 17.7 U/L). Mean follicular diameter on day $L H+O$ was $18.9 \mathrm{~mm}$ (range 14.5 to $24 \mathrm{~mm}$; standard deviation $2.2 \mathrm{~mm}$ ). Mean endometrial thickness on day $L H+O$ was $10.3 \mathrm{~mm}$ (range 7 to $13 \mathrm{~mm}$; standard deviation $1.4 \mathrm{~mm}$ ).

All patients showed a normal uterine cavity on hysterosalpingogram and histological analysis showed no endometrial pathology. According to the dating results, patients could be grouped as shown in Table 2. McNemar's test did not show any statistical difference among these values $(\mathrm{p}=36.33 \%)$.

\section{DISCUSSION}

Inadequate endometrial maturation is associated to many factors. ${ }^{(10)}$ This study excluded patients exhibiting a short luteal phase, low luteal phase progesterone secretion or hyperprolactinemia. Their cycles had follicular and luteal phases of normal length, and preovulatory follicular diameter ${ }^{(11)}$ and endometrial thickness ${ }^{(12)}$ were also normal.

Biopsies were performed on luteal phase days 6 and 10, according to the day of $\mathrm{LH}$ peak, which provides the best correlation for histological dating. ${ }^{(3,9,13)}$ Considering that the endometrial secretory phase is induced by progesterone, and the synthesis of this hormone is LH-dependent, taking the LH peak day as the reference appears to be the most appropriate. The biopsies were done on different uterine walls to minimize the interference of the first one with the second. ${ }^{(14)}$

Eight samples from day $\mathrm{LH}+6$ and five from day $L H+10$ showed maturation delay. As there was no statistical difference between these values, biopsies performed on either of these days seem to be equally effective for determining endometrial maturation.

These results differ from those of Castelbaum et al., ${ }^{(6)}$ who did endometrial dating according to the Noyes criteria, ${ }^{(2)}$ considering as out-of-phase a delay of 3 days or 
Table 1

Parameters of the cycles studied

\begin{tabular}{ccc}
\hline Parameter & Average \pm SD $^{*}$ & Range \\
\hline follicular phase length (days) & $14.60 \pm 2.21$ & 11 to 20 \\
luteal phase length (days) & $13.20 \pm 1.33$ & 12 to 17 \\
cycle length (days) & $27.8 \pm 2.35$ & 24 to 33 \\
basal FSH (U/l) & $5.30 \pm 1.77$ & 2.53 to 8.93 \\
basal LH $(\mathrm{U} / \mathrm{l})$ & $6.43 \pm 2.54$ & 1.51 to 9.92 \\
basal prolactin $(\mathrm{ng} / \mathrm{ml})$ & $8.41 \pm 4.03$ & 1.59 to 14.36 \\
progesterone on day $\mathrm{LH}+6(\mathrm{ng} / \mathrm{ml})$ & $14.4 \pm 4.5$ & 7.1 to 24.8 \\
\hline
\end{tabular}

${ }^{*} \mathrm{SD}$ = standard-deviation

Table 2

Distribution of endometrial dating on days $L H+6$ and $L H+10$

\begin{tabular}{lccc}
\hline & in phase, day LH+6 & out of phase, day LH+6 & TOTAL (\%) \\
\hline in phase, day $\mathrm{LH}+10$ & $14(56 \%)$ & $5(20 \%)$ & $19(76 \%)$ \\
out of phase, day LH+10 & $3(12 \%)$ & $3(12 \%)$ & $6(24 \%)$ \\
TOTAL & $17(68 \%)$ & $8(32 \%)$ & $25(100 \%)$ \\
\hline
\end{tabular}

more. Nevertheless, this apparent disagreement may be partially explained based on methodological differences. Unfortunately, there is no information on luteal phase length, prolactin levels, ovulation confirmation, uterine cavity shape or progesterone plasma levels in that paper. Consequently, these two study groups may be not comparable.
Although endometrial maturity can still be determined via other tests (biochemical, immunohistochemical, electron microscopy, etc), their cost/benefit ratios are prohibitive. Histological analysis remains the most useful method for evaluating endometrial maturation and the morphometric process, despite taking up more time, provides a more accurate result.

\section{RESUMO}

Contexto: A verificação da maturidade endometrial, elemento diagnóstico necessário na avaliação do casal com queixa de infertilidade, vem sendo feita desde 1950 através do critério de datação histológica de Noyes. No entanto, não existe um consenso em relação ao período da fase lútea mais adequado para a colheita. Objetivo: Avaliar a correlação entre as datações histológicas de duas amostras de endométrio colhidas nos dias 6 e 10 da fase lútea de um mesmo ciclo menstrual. Local: Setor de Reprodução Humana da Universidade Federal de São Paulo. Tipo de estudo: Estudo prospectivo. Constou da comparação entre duas datações de endométrio num mesmo ciclo menstrual. Participantes: 25 pacientes com queixa de infertilidade tiveram um ciclo menstrual monitorizado por ultra-sonografia e medida plasmática de LH, para demonstração de ovulação. Procedimento: Biópsias de endométrio foram feitas nos dias $\mathrm{LH}+6$ e $\mathrm{LH}+10$ da fase lútea, considerando-se o dia seguinte ao do pico de $\mathrm{LH}$ como LH+1. A datação foi feita de acordo com critério morfométrico, considerando-se o endométrio como fora de fase, se o atraso de maturação mínimo fosse de um dia. No dia $\mathrm{LH}+6$ foi feita dosagem de progesterona plasmática. Resultados: Todas as pacientes apresentaram ciclos ovulatórios (média dos valores de pico de $\mathrm{LH}$ : $47,3 \mathrm{U} / \mathrm{L}$; média dos diâmetros foliculares no dia do pico de LH: $18,9 \mathrm{~mm}$; média das espessuras do endométrio no dia do pico de LH: $10,3 \mathrm{~mm}$; média das concentrações de progesterona plasmática no dia LH+6: 14,4 ng/ml.). Em 14 pacientes, as duas biópsias estavam em fase. Houve atraso de maturação apenas no dia $\mathrm{LH}+6$ em cinco pacientes; apenas no dia $\mathrm{LH}+10$ em três pacientes e, nos dois dias, em três pacientes. Não houve diferença estatística entre esses valores (teste de McNemar, $p=33,36 \%$ ). Conclusões: Os resultados sugerem que a colheita do endométrio em qualquer dos dias (sexto ou décimo) da fase lútea fornece resultados semelhantes em relação à maturidade endometrial. 


\section{REFERENCES}

1. Jones GES. Some newer aspects of the management of infertility. JAMA 1949;141(16):1123-9.

2. Noyes RW, Hertig AT, Rock J. Dating the Endometrial Biopsy. Fertil Steril 1950;1(1):3-25.

3. Li TC, Rogers AW, Lenton EA, Dockery P, Cooke I. A comparison between two methods of chronological dating of human endometrial biopsies during the luteal phase, and their correlation with histologic dating. Fertil Steril 1987;48(6):928-32.

4. Tsibris JCM, Cazenave CR, Cantor B, Notelovitz M, Kalra PS, Spellacy WN. Distribution of cytoplasmatic estrogen and progesterone receptors in human endometrium. Am J Obstet Gynecol 1978;132(4):449-54.

5. Scott RT, Snyder RR, Strickland DM, et al. The effect of interobserver variation in dating endometrial histology on the diagnosis of luteal phase defects. Fertil Steril 1988;50(6):888-92.

6. Castelbaum AJ, Wheeler J, Coutifaris CB, Mastroianni Jr L, Lessey BA. Timing of the endometrial biopsy may be critical for the accurate diagnosis of luteal phase deficiency. Fertil Steril 1994;61(3):443-7.
7. Ritchie WGM. Sonographic evaluation of normal and induced ovulation. Radiology 1986;161:1-10.

8. Forrest TS, Elyaderani MK, Muilenburg MI, Bewtra C, Kable WT, Sullivan P. Cyclic endometrial changes: US assessment with histologic correlation. Radiology 1988;167:233-7.

9. Li TC, Rogers AW, Dockery P, Lenton EA, Cooke ID. A new method of histologic dating of human endometrium in the luteal phase. Fertil Steril 1988;50(1):52-60.

10. Mori H. New aspects of the physiology and pathology of the luteal phase: an overview. Horm Res 1992; 37(1): 3-4.

11. Randall JM, Templeton A. Transvaginal sonographic assessment of follicular and endometrial growth in spontaneous and clomiphene citrate cycles. Fertil Steril 1991;56(2):208-12.

12. Fleisher AC, Kepple DM, Herbert CM, Hill GA. Transvaginal sonography in gynecologic infertility. In Fleisher AC, editors. Diagnostic Imaging in Infertility. Baltimore:Williams \& Wilkins; 1992:242-68.

13. Tredway DR, Mishell DR, Moyer DL. Correlation of endometrial dating with luteinizing hormone peak. Am J Obstet Gynecol 1973;117(8):1030-3.

14. Li TC, Cooke ID. Outpatient endometrial biopsy: clinical, endocrinologic and histologic consequences. Int J Gynecol Obstet 1990;31:35-41. 